\title{
Birth influences future: examining discrimination against Chinese deputy mayors with grassroots administration origins
}

Ying Wang ${ }^{1} \&$ Lei Hua (1) ${ }^{2,3 凶}$

There is no systematic empirical study to address the unfair political treatment of Chinese officials with grassroots beginnings. This research addresses this gap by conducting theoretical and empirical studies. Drawing on a new biographical database of Chinese deputy mayors of municipal cities, this paper conducts competing risk regression and classical logistic regression modeling to examine the role of career starting level in deputy mayors' political careers. The empirical analysis provides solid results and demonstrates that the higher the career starting level, the greater the probability of getting promoted and the lower the risk of political downfall, which indicated that deputy mayors who started their careers in grassroots-level governments were associated with the lowest probabilities of promotion and highest risks of falling. The unfair political treatment is the tragedy of grassroots cadres and does not match the importance of grassroots work, which leads to great discontent and may threaten the sustainability of Communist Party rule in the future. 


\section{Introduction}

hinese officials' political careers are of great concern in academic circles and arouse many discussions among scholars. Under China's authoritarian system, subordinate officials are appointed by their superior standing committee of the CPC (Communist Party of China) committee. Based on this prevailing appointment system, research about Chinese officials' political careers has concentrated mostly on promotion patterns, in which the performance-based promotion and network-based promotion schools of thought have been well discussed (Zeng, 2013).

Performance-based promotion schools emphasize the role of merit in Chinese officials' political promotion. As the CPC pays more attention to economic development and economic competition, some scholars believe that economic performance such as GDP (gross domestic product) growth is the key factor in political promotion, and a considerable amount of empirical research has demonstrated a positive correlation between economic performance and political promotion of Chinese leaders (Bo, 1996, 2002; Landry, 2003; Chen et al., 2005; Li and Zhou, 2005; Choi, 2012; Lin, 2012). In addition to economic performance, some studies have shown that education qualifications play an equally important role in political promotion due to the implementation of the "four standards for cadres" policy ${ }^{1}$ (Lee, 1991; Shih et al., 2012; Lin, 2012; Zuo, 2015).

Network-based promotion schools argue that networks are more important than merit in Chinese officials' political promotion. In modern Chinese political research, the network that has been called guanxi (关系) by the Chinese plays an extremely vital role (Dittmer, 1995; Moody, 2009), the princelings' powerful family background has been considered crucial for them to win higher party ranks (Zheng and Fook, 2003; Zheng and Chen, 2009; Zeng, 2013), and the patron-client tie has been mentioned as an essential factor in selecting members of China's supreme decision-making body, the so-called Politburo Standing Committee (Li, 2012a, 2012b). The main assumption of network-based promotion theories is that Chinese leaders have to select loyal followers to survive fierce factional conflicts or maintain their political influence even in retirement (Pye, 1992; MacFarquhar and Schoenhals, 2006). Some studies have confirmed that central leadership utilizes network-based strategies to single out trustworthy and loyal subordinate officials for promotion (Shih et al., 2012; Opper et al., 2015).

Nevertheless, suicide and dismissal for corruption reflect another part of the Chinese official's political career, namely, their political falling. Similar to promotion patterns, some scholars identify economic development as the possible cause of corruption in China (Dong and Torgler, 2013). The political falling of Chinese officials is also considered closely related to the downfall of their patrons, which is guanxi. Although there is little empirical evidence for that claim, by observing Xi Jinping's anti-corruption campaign, we noticed that most officials who experienced investigation for corruption were on the side of the previous leader (i.e., in Jiang Zemin's faction), and those who were connected with current powerful leaders were more likely to survive.

Therefore, previous literature about Chinese officials' political careers has focused more on patterns of promotion or falling regarding political leadership, with very little effort to explore discrimination in Chinese politics. Some scholars have studied gender inequality in Chinese politics (Su, 2006; Tian and Bush, 2020). Another study examined discrimination against women, non-Han minorities, intellectuals, and non-communist members among current China's provincial political elites (Fu et al., 2018). However, to the best of our knowledge, there is no systematic empirical study that addresses the unfair political treatment of Chinese officials with grassroots beginnings.
In fact, the unfair economic and political treatment of Chinese officials starting at the grassroots level has become a serious but neglected problem that may threaten the Communist party rule. Officials who have their first step at the central and provincial governments can be promoted to department leaders sooner or later, as long as they work steadily without making serious mistakes (Fang and Ma, 2010). On the other hand, officials with their first step in grassroots-level governments find it much harder to obtain promotions and have a particularly wide range of responsibilities (O’Brien and Li, 1999; Perry and Goldman, 2007). They are required to be highly open-minded with an ability to solve complicated and acute problems related to the Party, the government and the villagers. Thus, complaints and a sense of unfairness among the grassroots cadres may gradually increase and may eventually devastate the basis that the country relies on to maintain stability.

We also noticed that prior empirical research on Chinese officials' political careers had mostly focused on the chief leaders of parties and governments, such as provincial party secretaries and governors, municipal party secretaries and mayors, and even county party secretaries and county mayors. There has been no systematic attempt to analyze the political promotion and falling of deputy leaders such as deputy governors or deputy mayors because of the political sensitivity or unavailability of the data source. In reality, it is much harder for researchers to obtain information about Chinese deputy leaders than chief leaders. China's authoritarian system emphasizes chief leaders' personal qualities and abilities more than the achievements obtained through teamwork. Information about chief leaders can be easily obtained from blogs, forums, social networks and portal websites, which is not true for deputy leaders.

To fill the above-mentioned research gaps, this paper draws on a new biographical database of Chinese deputy mayors of municipal cities and tries to examine discrimination in the political promotion and falling of Chinese deputy mayors with grassroots origins. The contribution of the present article is threefold. First, this is the only systematic empirical study addressing the unfair political treatment of Chinese officials starting at the grassroots level. The empirical analysis provides proof to illustrate the important influence that the career starting level of deputy mayors has on their promotions and falling. Second, the political career of Chinese deputy leaders has not been systematically explored but is vitally important. Promotion in the Chinese political system requires all chief leaders to have deputy experiences. Research on Chinese deputies' political careers can supplement the current literature and enhance the understanding of the Chinese political system. The third contribution of this study is to introduce competing risk regression modeling to analyze political career of Chinese officials, which has never been reported in the relevant literature before.

Based on the data of Chinese municipal deputy mayors who were incumbent at the end of 2008, we conducted competing risk regression and classical logistic regression modeling and found that the higher the starting level was, the greater the probability of getting promoted and the lower the risk of falling. Conversely, the deputy mayors who started their careers in grassroots-level governments were associated with the lowest probability of promotion and the highest risk of falling. Our findings are sobering because this "birth influences future" phenomenon not only threatens the sustainability of Communist party rule but is also detrimental to society.

Theoretical analysis and hypotheses can be found in section "Theoretical analysis and hypotheses". Section "Methods, measurement and data" describes the methods, measurements and 
data. Section "Empirical analysis and findings" presents the empirical analysis. Conclusions are presented in section "Conclusion" at the end.

\section{Theoretical analysis and hypotheses}

Background: Chinese officials' manic pursuits of political promotion. Our analysis is based on the premise of the official rank-oriented standard, “Guan Ben Wei (官本位)”, which has been prevailing for thousands of years and is deeply rooted in Chinese society (Lei, 2011; Pang et al., 2018a). The official rankoriented standard is a common practice in China by which people who hold administrative positions are more valued and respected because these people have social influence and power in society and can access more resources (Lei, 2011; Wang et al., 2014; Ying et al., 2017).

Since the establishment of the feudal system, China's society has been divided into several levels, in which, the higher the level is, the more privileges it possesses. During the continuous changes of the dynasty, although the hierarchical system has undergone some changes, officials' classes are always at the top of the system and involve privileges greater than those of other classes (Lei, 2011). Just as an old Chinese saying goes, "everything else is inferior, only being a scholar (an official) is supreme (万般 皆下品, 惟有读书高)". Being a scholar here is equivalent to being an official because "officialdom is the natural outlet for good scholars (学而优则仕)”. The official rank-oriented standard is deeply embedded into the culture and value system and continues to influence individuals' and organizations' ways of thinking and behaving (Lei, 2011; Xu, 2012; Wang et al., 2014; Wang and Xie, 2015; Ying et al., 2017; Pang et al., 2018a). In fact, under the autocracy of the $\mathrm{CPC}$, the official rank-oriented standard has been strengthened rather than weakened. In China, it has become common sense, or a hidden rule, that Chinese officials always have authority over the common people. Even the richest people have to show their respect to Chinese officials and loyalty to the CPC. Those who are disrespectful or disobedient to the ruling class will be punished. Wang Jianlin (王健林), China's former richest man, whose wealth was cut nearly in half over two years, is the perfect example of that.

The official's administrative title signifies not only one's social influence and power status but also gives individuals a sense of accomplishment and familial pride that is unmatched by any other career (Wang et al., 2014). Thus, getting further political promotion means almost everything to Chinese deputy mayors while dropping out of the government is commonly considered a failure.

The political promotion of Chinese deputy mayors. As a typical authoritarian regime, the CPC uses a pyramid-type ranking structure to divide Chinese officials into a series of administrative levels. The titles from the lowest to the highest are ordinary section member (keyuan 科员), deputy section level (fuke 副科 级), section level (zhengke 正科级), deputy county level ( $f u c h u$ 副 处级), county level (zhengchu 正处级), deputy municipal level (futing 副厅级), municipal level (zhengting 正厅级), subprovincial level (fusheng 副省级), provincial level (zhengsheng 正省级), sub-national level (fuguo 副国级) and national level (zhengguo 正国级). The subordinate official's political future is determined by the superior standing committee of the CPC committee. Therefore, catching the attention of superior leaders who hold power and building personal ties (guanxi) with them has become the critical mission.

However, deputy mayors with grassroots beginnings are at a natural disadvantage in establishing guanxi with superior leaders compared with deputy mayors who started with higher-level governments.

First, officials starting with higher-level governments have more opportunities to get in touch with higher-level leaders and establish personal ties with them. We noticed that the main assumption of network-based promotion theory is that Chinese leaders tend to select loyal followers rather than the most capable ones to maintain their leaderships, and many empirical studies have also demonstrated the importance of political loyalty in Chinese politics (Shih et al., 2012; Opper et al., 2015). However, leaders cannot distinguish subordinates who are actually trustworthy from those who are not unless a long-term connection exists. The officials who started with higher-level governments, especially the provincial-level governments and central-level governments, could form links with leaders in higher ranks earlier and have more time to build credibility and loyalty with these superior leaders. In other words, they could get ahead of those who started in the grassroots-level governments.

Second, Chinese officials tend to exchange political information and relationships through large networks of leaders and colleagues. The officials who started in higher levels of government can become acquainted with more powerful leaders and more promising colleagues, and thus have more political resources as well as knowing more about various informal and formal rules of high-level politics. Within the culture of homophilous associations, they can even be promoted directly by someone in their circles (Opper et al., 2015).

Thus, it is clear that starting at the grassroots level of China's administration cannot offer ambitious officials with any of the social capital that they need. The higher the level of government, the more power there is, which means more real network resources. Deputy mayors with grassroots government beginnings have significant disadvantages.

Apart from the acquired guanxi, deputy mayors who started in grassroots-level governments have great disadvantages based on their original family backgrounds compared with deputy mayors who started in higher-level governments.

The career starting level is to some extent a reflection of family background. The "state job allocation mode" (guojia fenpei 国家 分配: the state allocated job to individuals), which dominated the national job market for a very long period from the early 1950s to the late 1990s, had strict control of jobs and gave individuals no choice but to show their obedience to the collective (Bian, 1994). Individual ability and willingness were less important, while family background played an essential role in job allocation. For instance, children from affluent families tended to have a greater chance of being assigned in the privileged state sectors given that their high-status fathers might have a better connection with the job assigner (Bian, 1994). In fact, most Chinese leaders currently in power graduated before 2000, and they were all involved in the state job allocation program. The situation was more obvious for deputy mayors. The youngest deputy mayor in our dataset was already 35 years old by the end of 2008, and there is no doubt that all the rest were under the influence of this program. Given this situation, the career starting level was, in a way, reflective of the strength of family backgrounds and friendship circles.

In sum, the deputy mayors who started in higher-level governments have greater advantages over the deputy mayors who started in grassroots-level governments with respect to acquired guanxi and original family backgrounds, which are the factors that provide a greater probability for a deputy mayor to get promoted. Furthermore, the political promotion of deputy mayors mainly depends on guanxi and family backgrounds rather than capabilities (performance evaluation or capability examination), that is, discrimination. 
The political falling of Chinese deputy mayors. As discussed above, this paper argues that the higher career starting level means more powerful patrons or families. If this is true, we can make some interesting predictions about the political falling of Chinese deputy mayors; that is, the deputy mayors who started in higher-level governments should be consistently associated with a lower risk of a political falling. Just as an old Chinese saying goes, "Before you kick a dog, you'd better check with its owner (打狗也 要看主人)"; the powerful patron or family is not only the sponsor but also the protector of the officials.

Hypotheses. Based on the comprehensive analysis presented above, this paper accordingly offers two theoretical hypotheses:

Hypothesis 1. The higher the career starting levels are, the greater the probability for deputy mayors to get promoted. The deputy mayors who start their careers in grassroots-level governments will be associated with the lowest probability of promotion.

Hypothesis 2. The higher the career starting levels are, the lower the probability for deputy mayors to fall. The deputy mayors who start their careers in grassroots-level governments will be associated with the highest risk of falling.

\section{Methods, measurement, and data}

Statistical analysis methods. Two statistical approaches were used to test the foregoing hypotheses: time-dependent competing risk analysis and classical logistic regression.

The statistical analysis methods in this paper are mainly based on the competing risk regression model. The advantages are twofold. First, compared with classical logistic regression models, competing risk regression models can account not only for exit events but also for the timing of exits (Falk, 2013). Second, compared with the classic survival analysis method, a competing risk analysis method is more appropriate to use when individuals may exist for different causes (Porta et al., 2007).

The classical logistic regression model was also used to examine associations between promotion or falling and career starting level. Thus, this paper conducted a comprehensive comparative analysis by using two different statistical analysis methods with attempts to reduce errors by cross-referencing. The strictest criterion was set in this paper; only when a variable showed similar results, especially a result in the same direction, in all the models, can we conclude that this variable was effective in influencing the political promotion or political falling of Chinese deputy mayors.

It should be mentioned that the results of the competing risk regression model and classical logistic regression model report sub-distribution hazard ratios (SHR) and odds ratios (OR), respectively. Unlike the generally used estimated coefficient, the SHR and OR are used to examine how changes in each independent variable affect the direction and magnitude of changes in the dependent variable while other factors remain constant (Sin and Kim, 2008). A deputy mayor was more likely to get promotion or encounter falling if the independent variable had an SHR or OR higher than 1. The higher the SHR or OR was, the greater the chance or risk the deputy mayor will be promoted to the municipal level or encounter downfall. Conversely, a deputy mayor was less likely to be promoted to the municipal level or to encounter a fall if the independent variable had an SHR or OR lower than 1.

Key variables of interest. The political careers of Chinese officials are composed of two components: political promotion and political falling, which are the key variables in this study.
Political promotion. Competing risk regression models the subhazard function of an event of interest in the presence of competing events (Tervonen et al., 2017). In the competing risk analysis of deputy mayors' political promotion (Promotion_Competing_Risk), getting a promotion to the municipal level was the primary event of interest, and the competing event was leaving the official circle, which included retirement, corruption investigation, death and switching into the business. To account for the event of interest in the competing risk model, getting a promotion to the municipal level was coded as 1 , whereas leaving the official circle was coded as 2 . Deputy mayors who did not experience any event by the end of 2019 were censored and coded as 0 . Survival time (Time_Promotion) for each case was calculated from the date of starting their official careers to the date of getting promoted or leaving the official circle or December 2019, whichever occurred first.

For the classical logistic regression models, the key variable regarding political promotion (Promotion_Logistic) was a binary variable to check whether a deputy mayor had received a promotion by the end of 2019; if the deputy mayor was promoted to the municipal level, the variable was assigned a value of 1 , otherwise, it was assigned a value of 0 .

Political falling. In the competing risk analysis of deputy mayors' political falling (Falling_Competing_Risk), instances of political falling, including corruption investigation and unnatural death (e.g., homicide and suicide), was the primary event of interest. Peaceful falling, including natural death and switching into business, was regarded as competing event. To account for the event of interest in the competing risk model, political falling was coded as 1 , whereas peaceful falling was coded as 2 . Deputy mayors who did not experience any event by the end of 2019 were censored and coded as 0 . Survival time (Time_Falling) for each case was calculated from the date of starting their official careers to the date of political falling or peaceful falling or December 2019, whichever occurred first.

For the classical logistic regression models, the key variable of political falling (Falling_Logistic) was also binary, indicating whether a deputy mayor encountered a political fall by the end of 2019. Deputy mayors who were investigated for corruption or died of unnatural causes by the end of 2019 were assigned a value of 1 , while those who were not investigated or those who died of natural causes were assigned a value of 0 .

Core independent variable. The level of government where the deputy mayors started their official careers (Career Starting Level) is the core independent variable. The four starting levels of government were from the lowest to the highest, grassroots government, municipal government, provincial government and central government, which were labeled 1, 2, 3, and 4, respectively.

Control variables. Based on the information available from the deputy mayors' curriculum vitae and the previous literature on Chinese officials' political careers, 12 control variables were selected (Table 1). This paper considered the comparable personal characteristics of deputy mayors who were incumbent at the end of 2008, which had been tested in previous studies, such as the number of years a deputy mayor had been in the post (Tenure), age (Age) and gender (Gender). As a complement, this study also considered variables that have rarely been examined in prior studies but may help explain the political promotion and falling of Chinese deputy mayors, such as whether the deputy mayor was a non-Communist Party mayor (Party), whether the deputy mayor was a minority (Minority), whether the deputy 


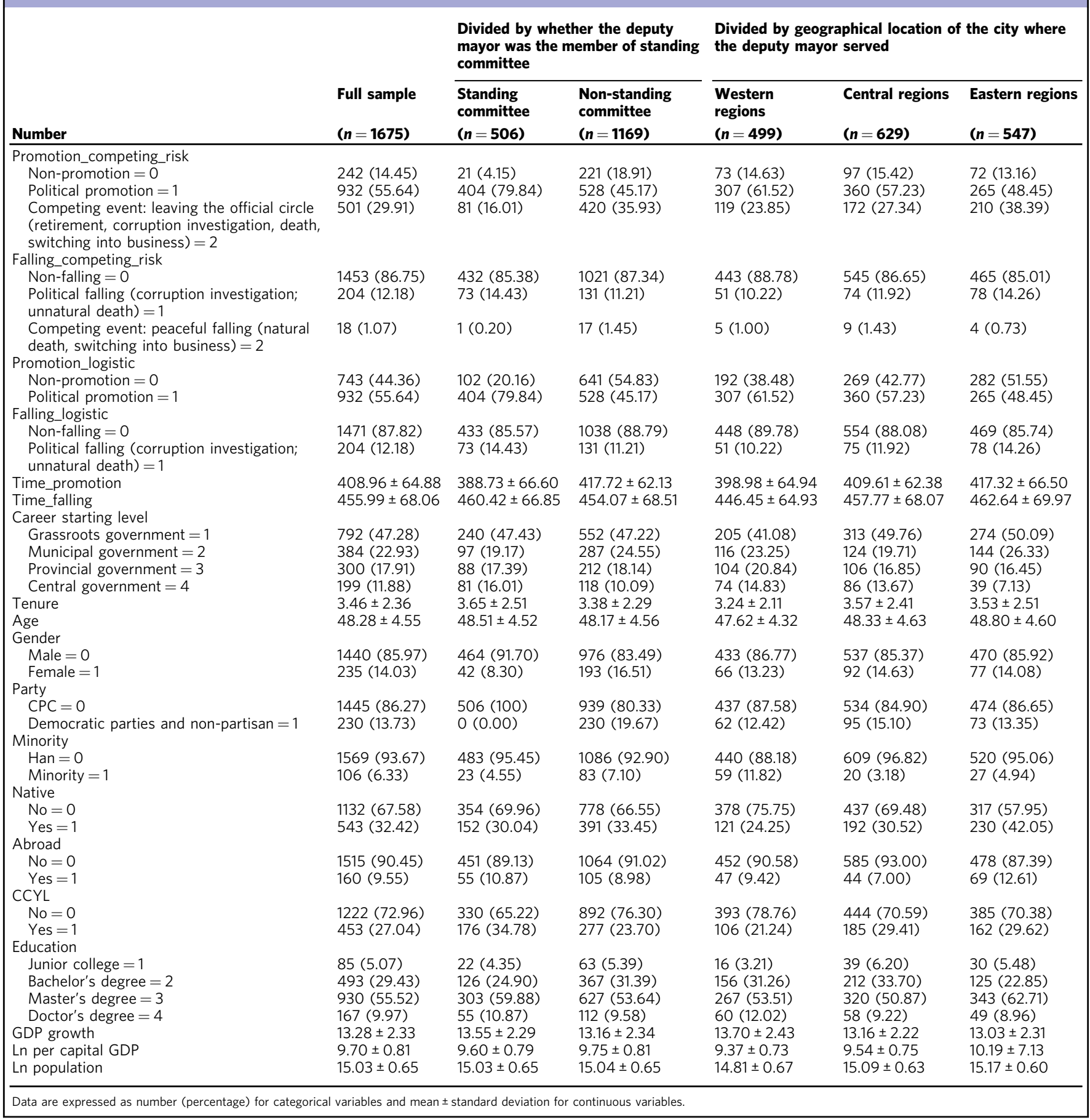

mayor was a native of the city where he (or she) served as deputy mayor (Native) and whether the deputy mayor had acquired the experience of studying abroad (Abroad). To capture potential network ties, we also introduced another variable, namely, whether the deputy mayor acquired work experience with China's Communist Youth League $(C C Y L)$.

It is worth mentioning the variable related to the government officials' capacities, which is an important issue in the study of officials' careers. To minimize the influence of officials' capacities on the conclusions of the study, this paper drew on a new biographical database of Chinese deputy mayors of municipal cities to determine whether they could have obtained further political promotions (i.e., get promoted to municipal-level cadres, which are considered high-ranking officials in Chinese official circles). Our statistics show that there are 2204 deputy mayors in China, accounting for $0.000157 \%$ of the national population; that is, the people who can be promoted to the position of deputy mayor are as rare as the hair of a phoenix. These people stand out in extremely fierce competition, which indicates that the actual level of variance in capacities among them shows little disparity. In addition, some empirical studies have also confirmed that performance plays a greater role in promotion at lower administrative levels of government, such as county-level cadres, while performance becomes irrelevant with the promotion of higher-level officials (Jia et al., 2015; Landry et al., 2018). It is the connection (guanxi 关系) that shows the large and statistically 
significant correlation with promotion of higher-level officials (such as promotion from deputy mayors to municipal-level officials), which is consistent with our theoretical analysis.

Although there is no concern about variability in government officials' capacities, to test the role of performance, this paper considered the average real GDP growth rate during the tenure of the deputy mayor (GDP Growth) ${ }^{2}$, development level (Ln Per Capital GDP) and educational qualification (Education) as measurement of merit. We also controlled for the population size ( $L n$ Population) of different cities. All GDP measurements were calculated at 2000 constant prices.

\section{Data}

Data source. This paper used data from Chinese deputy mayors in municipal cities (dijishi) in 2008 to conduct the empirical analysis $^{3}$. China promulgated its "Regulations on the Disclosure of Government Information" in 2007, which went into effect in 2008. Before that time, due to the political sensitivity of officials' personal histories, information on most Chinese officials below the provincial level was unknown to the public. Therefore, the data on Chinese municipal deputy mayors in 2008 are by far the best for investigating how the career starting level influences the promotion and falling of Chinese deputy officials.

We obtained the list of deputy mayors who were incumbent at the end of 2008 from the almanac of each city and conducted time-to-event research to determine whether these deputy mayors received a promotion or encountered a political fall by the end of 2019. Information on these mayors was compiled from the Baidu Encyclopedia and government official website of each city where their curriculum vitae was announced. The curriculum vitae contained detailed personal information about these mayors, including their age, education and work experience prior to the current appointment (Li and Zhou, 2005). The data also included the month and year when they took or left office and the nature of the change, e.g., promotion, lateral move, remaining in the same position or retirement (Li and Zhou, 2005). However, there were portions of mayors' curriculum vitae that remained incomplete or even missing. We finally obtained 1675 deputy mayors' curriculum vitae that contained the complete set of information that we needed, and those accounted for $76 \%$ of the total number of deputy mayors who were incumbent at the end of 2008.

Study samples. To ensure that our major findings are robust, this paper also conducted sensitivity tests by dividing the full sample into separate subsamples.

The standing committee of the CPC committee is the real power at all levels of Chinese government, and membership in the standing committee indicates an invisible higher-ranked position. Therefore, this paper categorized deputy mayors into separate sub-samples to further verify the role of career starting level, with 506 mayors considered standing committee members and 1169 considered non-standing committee members.

Moreover, based on the geographical location and economic development of the city where the deputy mayor served at the end of 2008, the full sample was split into three subsamples: western regions, central regions and eastern regions (see Fig. 1).

The statistical characteristics of the samples are shown in Table 1. As seen from the full sample, $55.64 \%$ of the Chinese deputy mayors were promoted to the municipal level, and $12.18 \%$ of the Chinese deputy mayors encountered political falling (corruption investigation and unnatural death) by the end of 2019. The proportions of standing committee deputy mayors who got promotion (79.84\%) and who encountered political falling $(14.43 \%)$ were higher than those of non-standing committee deputy mayors (45.17\% and $11.21 \%$, respectively). Interestingly, there existed a decreasing trend in the proportions of deputy mayors who got promotion from the western to the central to the eastern regions $(61.52 \%, 57.23 \%$, and $48.45 \%$, respectively), whereas the proportions of deputy mayors who encountered political falling presented an increasing trend $(10.22 \%, 11.92 \%$, and $14.26 \%$, respectively).

\section{Empirical analysis and findings}

In this section, empirical evidence on the impact of different career starting levels (Career Starting Level) on the political promotion and political falling of Chinese deputy mayors is presented.

The effects of different career starting levels on deputy mayors' political promotion. By taking time into account, the Fine-Gray competing risk method was used to calculate the cumulative incidence of political promotion, and the sub-distribution hazard ratios are reported in Table 2. Deputy mayors who started in grassroots-level governments were regarded as the reference condition to investigate the relative risk (promotion probability) of deputy mayors starting in other levels of governments.

From Table 2, we can clearly see that compared with the grassroots beginning, the sub-distribution hazard ratios of the other three career starting levels are all higher than 1 and become much higher with improvements in the government level indicated by the higher risk (promotion probability). Similar increasing trends were observed not only in the full sample but also in the sub-samples divided by geography and by membership in the standing committee, despite the insignificance of beginning in the municipal government in Model (2), Model (4) and Model (6). Specifically, we take the competing risk regression results of the full sample as an example: the sub-distribution hazard ratios for beginning in the municipal government, provincial government, and central government are 1.32, 1.78, and 2.72, respectively, when compared with beginning at the grassroots level. With advancing career starting levels, the promotion risk (probability) shows surprisingly increasing trends, which revealed that the deputy mayors starting their careers in the grassroots-level governments were associated with the lowest risk (probability) of promotion. The cumulative incidence function curves for the full sample and sub-samples are plotted in Fig. 2 and show the higher cumulative rate of political promotion in deputy mayors with higher career starting levels. Furthermore, deputy mayors who started in the grassroots-level governments always had the lowest cumulative political promotion rates. To summarize, the competing risk regression results strongly confirmed Hypothesis 1 .

By excluding the survival time, the probabilities of political promotion for Chinese deputy mayors were explored using classical logistic regression models, and the results are presented as odds ratios in Table 3. From Table 3, we can also clearly observe the increase in odds ratios with improvements in the initial government level. Specifically, we again take the regression results of the full sample as an example: the odds ratios are 1.36, 1.91 and 2.54, corresponding to the different levels of Chinese governments from municipal to central. This indicated that the chances that the deputy mayors who started their official careers in municipal, provincial and central governments will get promoted to the municipal-level cadres is $1.36,1.91$ and 2.54 times higher, respectively, than the deputy mayors who started in the grassroots-level governments. The classical logistic regression results also provide strong empirical support for Hypothesis 1.

For the control variables, we compared the results in Tables 2 and 3 and found that Education, GDP Growth and Ln Per Capital $G D P$, which present officials' merits, showed nonsignificant or uncertain effects on political promotion, indicating that deputy mayors' opportunities to serve in chief positions were not 


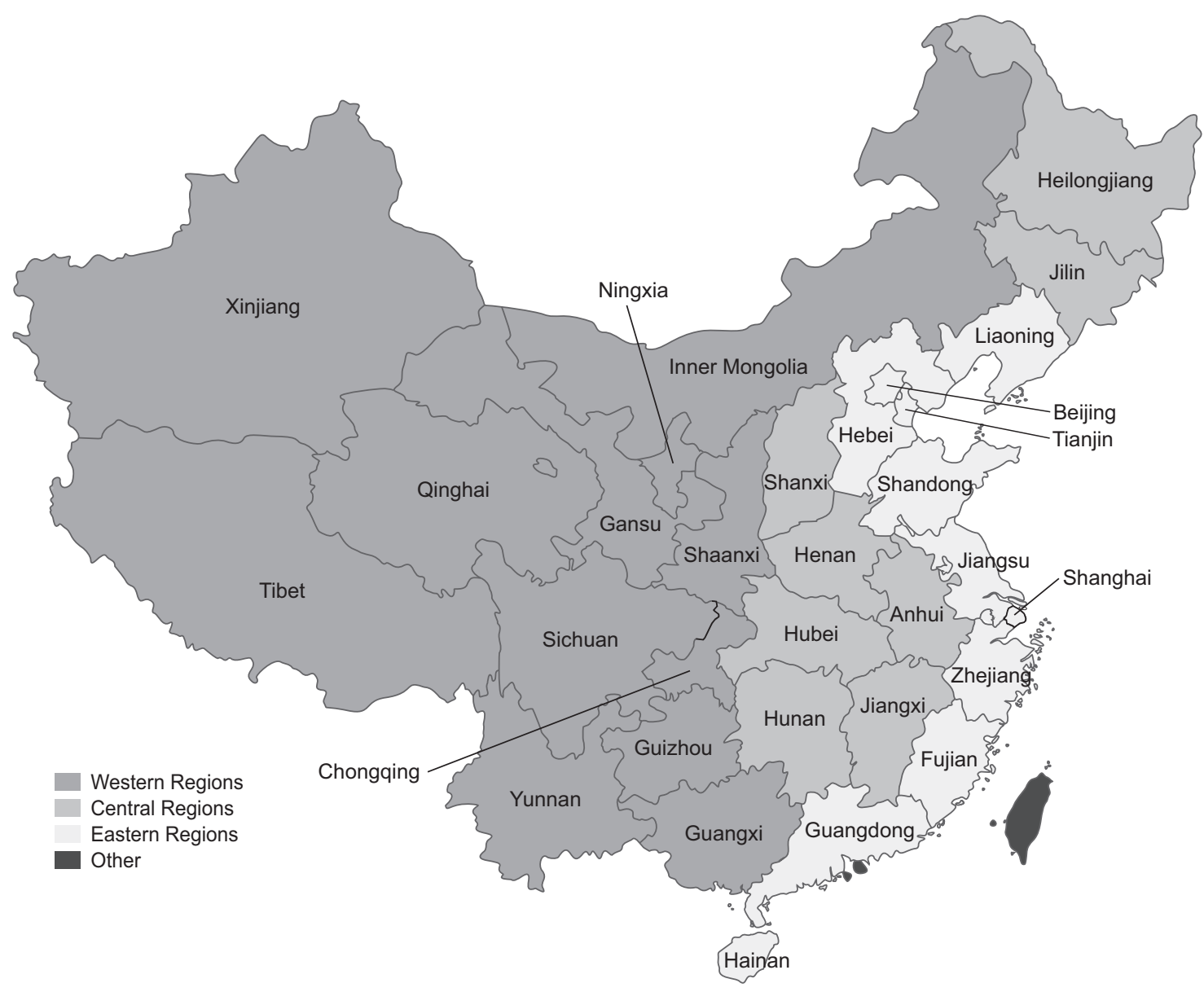

Fig. 1 Western regions, central regions and eastern regions of China. The regions in China were geographically and economically divided into three areas: western regions, central regions, and eastern regions.

determined by their capabilities or performances. This result should be understood as discrimination (Fu et al., 2018). In addition, Age and non-communist party membership (Party) were negatively correlated with promotion, which is consistent with previous literature ( $\mathrm{Li}$ and Zhou, 2005; Fu et al., 2018).

The effects of different career starting levels on deputy mayors' political falling. Similar to the foregoing analysis methods, by taking time into account, the cumulative incidence of political falling was calculated using the Fine-Gray competing risk method, and the sub-distribution hazard ratios are reported in Table 4. Deputy mayors who started in the grassroots-level governments were regarded as the reference condition.

From Table 4, we can clearly see that compared with the grassroots beginning, the other three career starting levels had sub-hazard ratios that are all lower than 1 and become much lower with improvements in the government level, which indicated the lower risk of political falling. Similar trends can be observed not only in the full sample but also in the subsamples divided by geography and by the membership in the standing committee. With advancing starting levels of government, the risk of political falling shows decreasing trends, which revealed that the deputy mayors who started their careers in the grassroots-level governments were associated with the highest risk of political falling. The cumulative incidence function curves for the full sample and sub-samples are plotted in Fig. 3 and show the lower cumulative rate of political falling in deputy mayors with the higher career starting levels. Furthermore, deputy mayors who started in the grassroots-level governments always had the highest cumulative political falling rates. To summarize, the competing risk regression results prove Hypothesis 2.

However, it is worthwhile to note that there existed an unsatisfactory significance level with beginnings at municipal government and provincial government levels. The reasons for this phenomenon may lie in the fact that political falling has little relation to survival time. Therefore, by excluding the time factor, classical logistic regression modeling was used to calculate the probabilities of political falling for Chinese deputy mayors, and the results are presented as odds ratios in Table 5.

The trends of decreased odds ratios with improvements in the government level are presented in Table 5, which indicated that there existed a decreased risk of political falling with increasing career starting levels. Moreover, the significance levels of beginning at the municipal government and provincial government levels were improved when excluding the survival time. Although municipal government beginnings were not always significant, the odds ratios were low enough to show the difference between beginning at the municipal government and grassroots government levels. The classical logistic regression results also strongly confirmed Hypothesis 2 .

For the control variables, by combining the results in Tables 4 and 5, it is worth noting that Age showed a significant negative correlation with political falling in the competing risk regression results, which reflected the underlying rule in Chinese official circles that "when you can forgive the old man, please forgive". In addition, female and non-communist party membership deputy 
Table 2 The competing risk regression results estimating the effect of different career starting levels on political promotion.

\begin{tabular}{|c|c|c|c|c|c|c|}
\hline & SHR & $\begin{array}{l}\text { (2) Standing } \\
\text { committee } \\
\text { SHR }\end{array}$ & $\begin{array}{l}\text { (3) Non-Standing } \\
\text { committee } \\
\text { SHR }\end{array}$ & SHR & SHR & SHR \\
\hline \multicolumn{7}{|l|}{ Career starting level } \\
\hline Grassroots government $=1$ & reference & & & & & \\
\hline Municipal government $=2$ & $1.32^{\star \star \star}(3.07)$ & $1.19(1.12)$ & $1.47^{\star \star \star}(3.33)$ & $1.22(1.18)$ & $1.42^{\star \star}(2.45)$ & $1.26(1.41)$ \\
\hline Provincial government $=3$ & $1.78^{\star \star \star}(5.33)$ & $1.85^{\star \star \star}(3.50)$ & $1.98^{\star \star \star}(4.98)$ & $1.87^{\star \star \star}(3.65)$ & $1.62^{\star \star \star}(2.85)$ & $1.96^{\star \star \star}(3.05)$ \\
\hline Central government $=4$ & $2.72^{\star \star \star}(7.03)$ & $2.27^{\star \star \star}(4.63)$ & $2.84^{\star \star \star}(5.17)$ & $2.38^{\star \star \star}(3.74)$ & $2.78^{\star \star \star}(5.12)$ & $3.93^{\star \star \star}(4.70)$ \\
\hline Tenure & $1.05^{\star \star}(2.54)$ & $0.96(-1.40)$ & $1.07^{\star \star \star}(2.83)$ & $1.10^{\star \star \star}(2.62)$ & $1.08^{\star \star \star}(2.95)$ & $0.96(-1.22)$ \\
\hline Age & $0.86^{\star \star \star}(-11.83)$ & $0.85^{\star \star \star}(-9.14)$ & $0.84^{\star \star \star}(-10.44)$ & $0.84^{\star \star \star}(-8.28)$ & $0.88^{\star \star \star}(-7.21)$ & $0.85^{\star \star \star}(-7.01)$ \\
\hline \multicolumn{7}{|l|}{ Gender } \\
\hline Male $=0$ & reference & & & & & \\
\hline Female $=1$ & $0.93(-0.59)$ & $1.30^{*}(1.65)$ & $0.90(-0.76)$ & $0.89(-0.61)$ & $0.78(-1.22)$ & $1.33(1.51)$ \\
\hline \multicolumn{7}{|l|}{ Party } \\
\hline $\mathrm{CPC}=0$ & reference & & & & & \\
\hline $\begin{array}{l}\text { Democratic parties and non- } \\
\text { partisan }=1\end{array}$ & $0.37^{\star \star \star}(-6.73)$ & 1 (omitted) & $0.49^{\star \star \star}(-4.44)$ & $0.33^{\star \star \star}(-4.31)$ & $0.38^{\star \star \star}(-4.36)$ & $0.32^{\star \star \star}(-3.59)$ \\
\hline \multicolumn{7}{|l|}{ Minority } \\
\hline $\mathrm{Han}=0$ & reference & & & & & \\
\hline Minority = 1 & $0.94(-0.46)$ & $0.64(-1.25)$ & $1.11(0.62)$ & $0.99(-0.04)$ & $0.61(-1.26)$ & $0.88(-0.35)$ \\
\hline \multicolumn{7}{|l|}{ Native } \\
\hline $\mathrm{No}=0$ & reference & & & & & \\
\hline Yes $=1$ & $0.93(-0.92)$ & $0.98(-0.17)$ & $0.92(-0.81)$ & $1.06(0.36)$ & $0.90(-0.79)$ & $1.00(0.00)$ \\
\hline \multicolumn{7}{|l|}{ Abroad } \\
\hline $\mathrm{No}=0$ & reference & & & & & \\
\hline Yes $=1$ & $1.07(0.49)$ & $0.83(-0.88)$ & $1.15(0.73)$ & $0.76(-1.00)$ & $1.77^{\star \star}(2.67)$ & $1.14(0.60)$ \\
\hline \multicolumn{7}{|l|}{ CCYL } \\
\hline $\mathrm{No}=0$ & reference & & & & & \\
\hline Yes $=1$ & $1.15^{\star}(1.74)$ & $1.02(0.18)$ & $1.12(1.06)$ & $0.99(-0.07)$ & $1.15(1.09)$ & $1.35^{\star \star}(2.00)$ \\
\hline \multicolumn{7}{|l|}{ Education } \\
\hline Junior college $=1$ & reference & & & & & \\
\hline Bachelor's degree $=2$ & $1.26(1.24)$ & $1.40(1.16)$ & $1.21(0.74)$ & $1.27(0.60)$ & $1.08(0.33)$ & $1.42(0.78)$ \\
\hline Master's degree $=3$ & $1.50^{\star \star}(2.23)$ & $1.22(0.71)$ & $1.56^{*}(1.74)$ & $1.37(0.79)$ & $1.24(0.91)$ & $2.62^{\star \star}(2.29)$ \\
\hline Doctor's degree $=4$ & $1.92^{\star \star \star}(2.74)$ & $1.88^{*}(1.84)$ & $1.64(1.48)$ & $1.96(1.41)$ & $1.86^{\star \star}(1.99)$ & $2.71^{\star}(1.87)$ \\
\hline GDP growth & $1.05^{\star \star \star}(2.99)$ & $1.04(1.41)$ & $1.06^{\star \star}(2.53)$ & $1.04(1.35)$ & $1.05^{\star \star}(2.08)$ & $1.10^{\star \star}(2.41)$ \\
\hline Ln per capital GDP & $0.86^{\star \star \star}(-3.10)$ & $0.81^{\star \star \star}(-2.80)$ & $0.95(-0.76)$ & $0.94(-0.64)$ & $1.00(-0.05)$ & $0.74^{\star \star \star}(-2.61)$ \\
\hline Ln population & $0.91(-1.41)$ & $1.11(1.05)$ & $0.86^{\star}(-1.93)$ & $1.01(0.08)$ & $0.89(-1.13)$ & $1.01(0.08)$ \\
\hline Number of observations & 1675 & 506 & 1169 & 499 & 629 & 547 \\
\hline Wald Chi-square & $354.73^{\star \star \star}$ & $258.57^{\star \star \star}$ & $260.16^{\star \star \star}$ & $159.94^{\star \star \star}$ & $168.22^{\star \star \star}$ & $166.38^{\star \star \star}$ \\
\hline
\end{tabular}
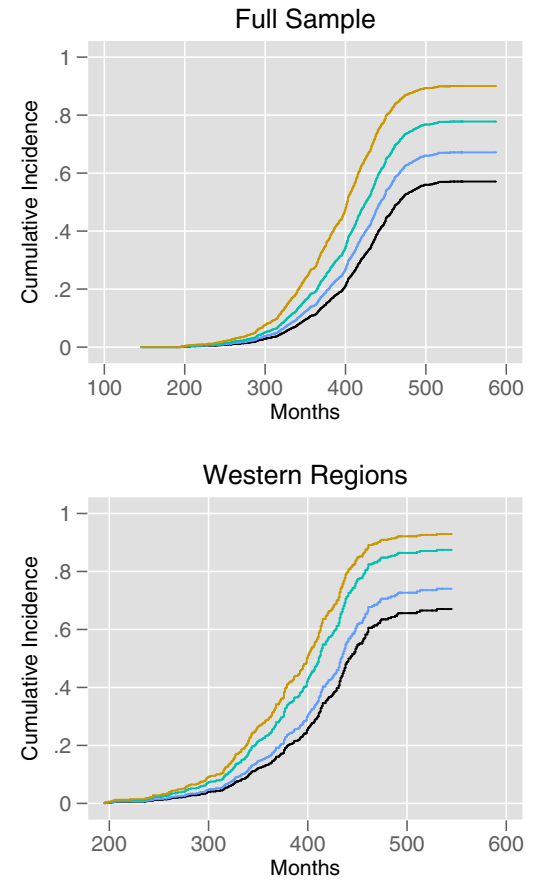

\section{- Career Starting Level = Grassroots Government Career Starting Level $=$ Provincial Government \\ - Career Starting Level = Municipal Government Career Starting Level $=$ Central Government}
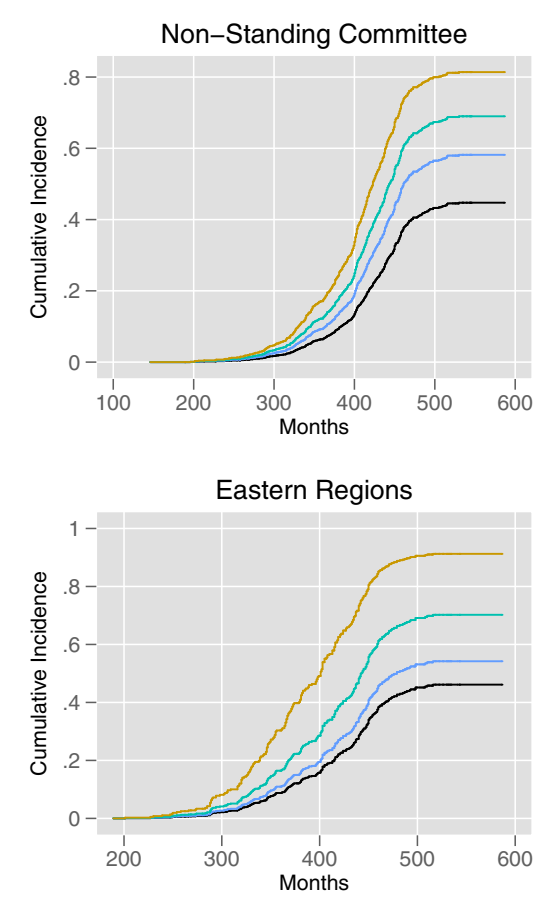

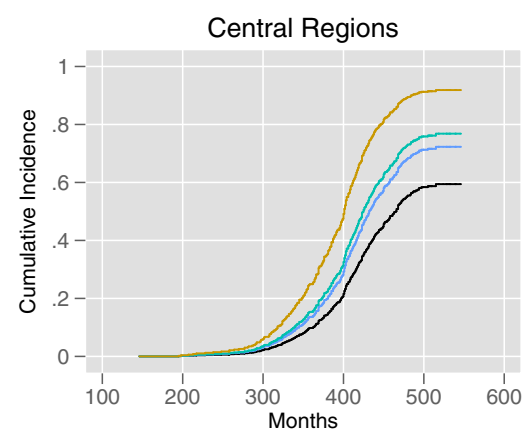

Standing Committee

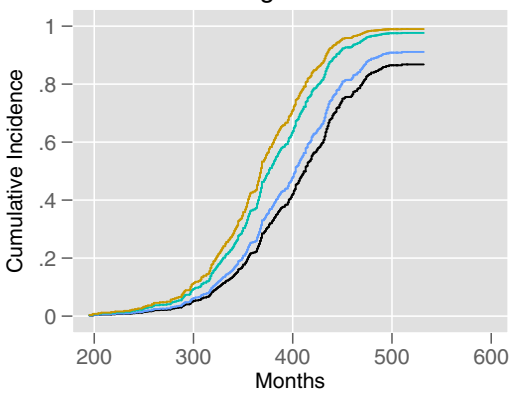

Fig. 2 The cumulative incidence curves of risk of political promotion. The cumulative incidence curves of political promotion from the highest to the lowest are central government beginnings, provincial government beginnings, municipal government beginnings and grassroots government beginnings, which indicates that deputy mayors with higher career starting levels have higher cumulative rate of political promotion. Thus, deputy mayors who started in the grassroots-level governments always had the lowest cumulative political promotion rates. 
Table 3 The logistic regression results estimating the effect of different career starting levels on political promotion.

\begin{tabular}{|c|c|c|c|c|c|c|}
\hline & Odds ratios & $\begin{array}{l}\text { (8) Standing } \\
\text { committee } \\
\text { Odds ratios }\end{array}$ & $\begin{array}{l}\text { (9) Non-Standing } \\
\text { committee } \\
\text { Odds ratios }\end{array}$ & Odds ratios & Odds ratios & Odds ratios \\
\hline \multicolumn{7}{|l|}{ Career starting level } \\
\hline Grassroots government $=1$ & reference & & & & & \\
\hline Municipal government $=2$ & $1.36^{\star \star}(2.22)$ & $1.60(1.48)$ & $1.45^{\star \star}(2.31)$ & $1.22(0.79)$ & $1.51^{\star}(1.75)$ & $1.32(1.16)$ \\
\hline Provincial government $=3$ & $1.91^{\star \star \star}(4.04)$ & $1.81(1.56)$ & $2.17^{\star \star \star}(4.15)$ & $1.82^{\star \star}(2.04)$ & $1.90^{\star \star}(2.44)$ & $2.16^{\star \star}(2.51)$ \\
\hline Central government $=4$ & $2.54^{\star \star \star}(4.55)$ & $2.49^{\star}(1.83)$ & $2.43^{\star \star \star}(3.67)$ & $2.88^{\star \star \star}(2.75)$ & $2.49^{\star \star \star}(3.03)$ & $3.14^{\star \star}(2.48)$ \\
\hline Tenure & $1.08^{\star \star \star}(2.93)$ & $0.95(-1.01)$ & $1.11^{\star \star \star}(3.06)$ & $1.14^{\star \star}(2.29)$ & $1.18^{\star \star \star}(3.72)$ & $0.95(-1.05)$ \\
\hline Age & $0.91^{\star \star \star}(-6.23)$ & $0.91^{\star \star \star}(-2.83)$ & $0.89^{\star \star \star}(-6.20)$ & $0.90^{\star \star \star}(-3.39)$ & $0.94^{\star \star \star}(-2.73)$ & $0.87^{\star \star \star}(-4.70)$ \\
\hline \multicolumn{7}{|l|}{ Gender } \\
\hline Male $=0$ & reference & & & & & \\
\hline Female $=1$ & $0.81(-1.26)$ & $1.11(0.24)$ & $0.80(-1.19)$ & $0.80(-0.68)$ & $0.66(-1.60)$ & $1.29(0.79)$ \\
\hline \multicolumn{7}{|l|}{ Party } \\
\hline$C P C=0$ & reference & & & & & \\
\hline $\begin{array}{l}\text { Democratic parties and non- } \\
\text { partisan }=1\end{array}$ & $0.22^{\star \star \star}(-8.31)$ & 1 (omitted) & $0.32^{\star \star \star}(-5.98)$ & $0.16^{\star \star \star}(-5.28)$ & $0.26^{\star \star \star}(-4.81)$ & $0.16^{\star \star \star}(-4.86)$ \\
\hline \multicolumn{7}{|l|}{ Minority } \\
\hline $\mathrm{Han}=0$ & reference & & & & & \\
\hline Minority $=1$ & $0.79(-1.07)$ & $0.32^{\star \star}(-2.32)$ & $1.06(0.24)$ & $1.05(0.16)$ & $0.44^{\star}(-1.65)$ & $0.65(-0.89)$ \\
\hline \multicolumn{7}{|l|}{ Native } \\
\hline $\mathrm{No}=0$ & reference & & & & & \\
\hline Yes $=1$ & $0.88(-1.02)$ & $0.88(-0.48)$ & $0.90(-0.72)$ & $0.95(-0.19)$ & $0.83(-0.96)$ & $1.01(0.03)$ \\
\hline \multicolumn{7}{|l|}{ Abroad } \\
\hline $\mathrm{No}=0$ & reference & & & & & \\
\hline Yes $=1$ & $1.01(0.07)$ & $0.78(-0.58)$ & $0.95(-0.23)$ & $1.05(0.12)$ & $0.92(-0.24)$ & $1.16(0.46)$ \\
\hline \multicolumn{7}{|l|}{ CCYL } \\
\hline $\mathrm{No}=0$ & reference & & & & & \\
\hline Yes $=1$ & $1.31^{\star \star}(2.17)$ & $1.18(0.63)$ & $1.20(1.18)$ & $1.13(0.47)$ & $1.44^{\star}(1.80)$ & $1.39(1.48)$ \\
\hline \multicolumn{7}{|l|}{ Education } \\
\hline Junior college $==1$ & reference & & & & & \\
\hline Bachelor's degree $=2$ & $1.43(1.37)$ & $1.39(0.63)$ & $1.45(1.13)$ & $1.41(0.59)$ & $1.13(0.33)$ & $1.77(1.06)$ \\
\hline Master's degree $=3$ & $1.99^{\star \star \star}(2.69)$ & $1.33(0.56)$ & $2.12^{\star \star}(2.31)$ & $1.53(0.73)$ & $1.72(1.43)$ & $3.94^{\star \star \star}(2.65)$ \\
\hline Doctor's degree $=4$ & $1.88^{\star \star}(1.96)$ & $4.95^{\star}(1.78)$ & $1.52(1.06)$ & $1.18(0.24)$ & $1.97(1.39)$ & $3.46^{\star *}(1.96)$ \\
\hline GDP growth & $1.05^{\star \star}(2.02)$ & $1.04(0.77)$ & $1.05^{\star}(1.68)$ & $1.02(0.43)$ & $1.09^{\star \star}(2.16)$ & $1.09^{\star}(1.67)$ \\
\hline Ln per capital GDP & $0.75^{\star \star \star}(-3.94)$ & $0.58^{\star \star \star}(-3.35)$ & $0.86^{\star}(-1.79)$ & $0.85(-0.96)$ & $1.02(0.12)$ & $0.54^{\star \star \star}(-3.60)$ \\
\hline Ln Population & $0.80^{\star \star}(-2.48)$ & $0.97(-0.13)$ & $0.77^{\star \star}(-2.40)$ & $0.70^{\star \star}(-2.05)$ & $0.97(-0.17)$ & $0.89(-0.64)$ \\
\hline Number of observations & 1675 & 506 & 1169 & 499 & 629 & 547 \\
\hline LR Chi-square & $277.28^{\star \star \star}$ & $61.05^{\star \star \star}$ & $180.47^{\star \star \star}$ & $78.72^{\star \star \star}$ & $92.37^{\star \star \star}$ & $139.46^{\star \star \star}$ \\
\hline
\end{tabular}

Table 4 The competing risk regression results estimating the effect of different career starting levels on political falling.

\begin{tabular}{|c|c|c|c|c|c|c|}
\hline & $\begin{array}{l}\text { (13) Full sample } \\
\text { SHR }\end{array}$ & $\begin{array}{l}\text { (14) Standing } \\
\text { committee } \\
\text { SHR }\end{array}$ & $\begin{array}{l}\text { (15) Non-Standing } \\
\text { committee } \\
\text { SHR }\end{array}$ & $\begin{array}{l}\text { (16) Western regions } \\
\text { SHR }\end{array}$ & $\begin{array}{l}\text { (17) Central regions } \\
\text { SHR }\end{array}$ & $\begin{array}{l}\text { (18) Eastern regions } \\
\text { SHR }\end{array}$ \\
\hline \multicolumn{7}{|l|}{ Career starting level } \\
\hline Grassroots government $=1$ & Reference & & & & & \\
\hline Municipal government $=2$ & $0.88(-0.72)$ & $0.78(-0.74)$ & $0.94(-0.27)$ & $0.81(-0.53)$ & $0.89(-0.37)$ & $0.90(-0.37)$ \\
\hline Provincial government $=3$ & $0.70(-1.63)$ & $0.75(-0.77)$ & $0.67(-1.45)$ & $0.69(-0.95)$ & $0.55(-1.45)$ & $0.84(-0.47)$ \\
\hline Central government $=4$ & $0.41^{\star \star}(-2.58)$ & $0.41^{\star}(-1.85)$ & $0.41^{\star}(-1.82)$ & $0.26^{\star \star}(-2.15)$ & $0.40^{\star}(-1.72)$ & $0.60(-0.84)$ \\
\hline Tenure & $0.99(-0.27)$ & $1.05(0.96)$ & $0.94(-1.37)$ & $1.07(0.79)$ & $0.95(-0.82)$ & $0.98(-0.34)$ \\
\hline Age & $0.82^{\star \star \star}(-9.11)$ & $0.82^{\star \star \star}(-5.12)$ & $0.83^{\star \star \star}(-7.05)$ & $0.81^{\star \star \star}(-4.75)$ & $0.85^{\star \star \star}(-4.20)$ & $0.79^{\star \star \star}(-6.86)$ \\
\hline \multicolumn{7}{|l|}{ Gender } \\
\hline Male $=0$ & Reference & & & & & \\
\hline Female $=1$ & $0.33^{\star \star \star \star}(-3.07)$ & $0.33(-1.46)$ & $0.35^{\star \star}(-2.56)$ & $0.17^{\star}(-1.82)$ & $0.46(-1.57)$ & $0.23^{\star \star}(-2.01)$ \\
\hline \multicolumn{7}{|l|}{ Party } \\
\hline $\mathrm{CPC}=0$ & Reference & & & & & \\
\hline $\begin{array}{l}\text { Democratic parties and non- } \\
\text { partisan }=1\end{array}$ & $0.41^{\star \star}(-2.46)$ & 1 (omitted) & $0.46^{\star \star}(-2.06)$ & $0.20^{\star}(-1.68)$ & $0.27^{\star \star}(-2.18)$ & $0.82(-0.34)$ \\
\hline \multicolumn{7}{|l|}{ Minority } \\
\hline $\mathrm{Han}=0$ & Reference & & & & & \\
\hline Minority = 1 & $0.66(-1.15)$ & $0.65(-0.61)$ & $0.70(-0.87)$ & $0.70(-0.72)$ & $0.55(-0.63)$ & $0.65(-0.58)$ \\
\hline \multicolumn{7}{|l|}{ Native } \\
\hline $\mathrm{No}=0$ & Reference & & & & & \\
\hline Yes $=1$ & $1.33^{*}(1.78)$ & $1.16(0.58)$ & $1.45^{\star}(1.86)$ & $1.49(1.15)$ & $1.22(0.78)$ & $1.29(0.94)$ \\
\hline \multicolumn{7}{|l|}{ Abroad } \\
\hline $\mathrm{No}=0$ & Reference & & & & & \\
\hline Yes $=1$ & $0.66(-1.35)$ & $0.71(-0.79)$ & $0.58(-1.16)$ & $1.21(0.35)$ & $0.47(-1.00)$ & $0.52(-1.36)$ \\
\hline \multicolumn{7}{|l|}{ CCYL } \\
\hline $\mathrm{No}=0$ & Reference & & & & & \\
\hline Yes $=1$ & $0.83(-1.18)$ & $0.65(-1.55)$ & $0.93(-0.36)$ & $0.67(-1.00)$ & $0.78(-0.91)$ & $0.92(-0.31)$ \\
\hline \multicolumn{7}{|l|}{ Education } \\
\hline Junior college $=1$ & Reference & & & & & \\
\hline Bachelor's degree $=2$ & $0.74(-1.00)$ & $1.39(0.54)$ & $0.57(-1.56)$ & $0.40(-1.27)$ & $0.64(-1.03)$ & $1.54(0.75)$ \\
\hline Master's degree $=3$ & $0.77(-0.86)$ & $1.43(0.63)$ & $0.57(-1.53)$ & $0.80(-0.32)$ & $0.66(-0.94)$ & $1.04(0.08)$ \\
\hline Doctor's degree $=4$ & $1.21(0.49)$ & $1.91(0.91)$ & $1.04(0.08)$ & $1.29(0.28)$ & $0.98(-0.03)$ & $1.70(0.78)$ \\
\hline GDP growth & $1.10^{\star \star \star}(2.90)$ & $1.11^{\star \star}(2.11)$ & $1.10^{\star \star}(2.20)$ & $1.13^{\star \star}(2.44)$ & $1.06(1.26)$ & $1.11(1.63)$ \\
\hline Ln per capital GDP & $1.13(1.26)$ & $1.23(1.31)$ & $1.08(0.57)$ & $1.15(0.52)$ & $0.90(-0.57)$ & $1.16(0.76)$ \\
\hline Ln Population & $1.17(1.27)$ & $1.30(1.28)$ & $1.09(0.57)$ & $0.97(-0.11)$ & $1.02(0.07)$ & $1.28(1.30)$ \\
\hline Number of observations & 1675 & 506 & 1169 & 499 & 629 & 547 \\
\hline Wald Chi-square & $156.56^{\star * \star}$ & $41.19^{\star \star \star}$ & $129.73^{\star \star \star}$ & $65.24^{\star \star \star}$ & $46.31^{\star \star \star}$ & $79.46^{\star \star \star}$ \\
\hline
\end{tabular}



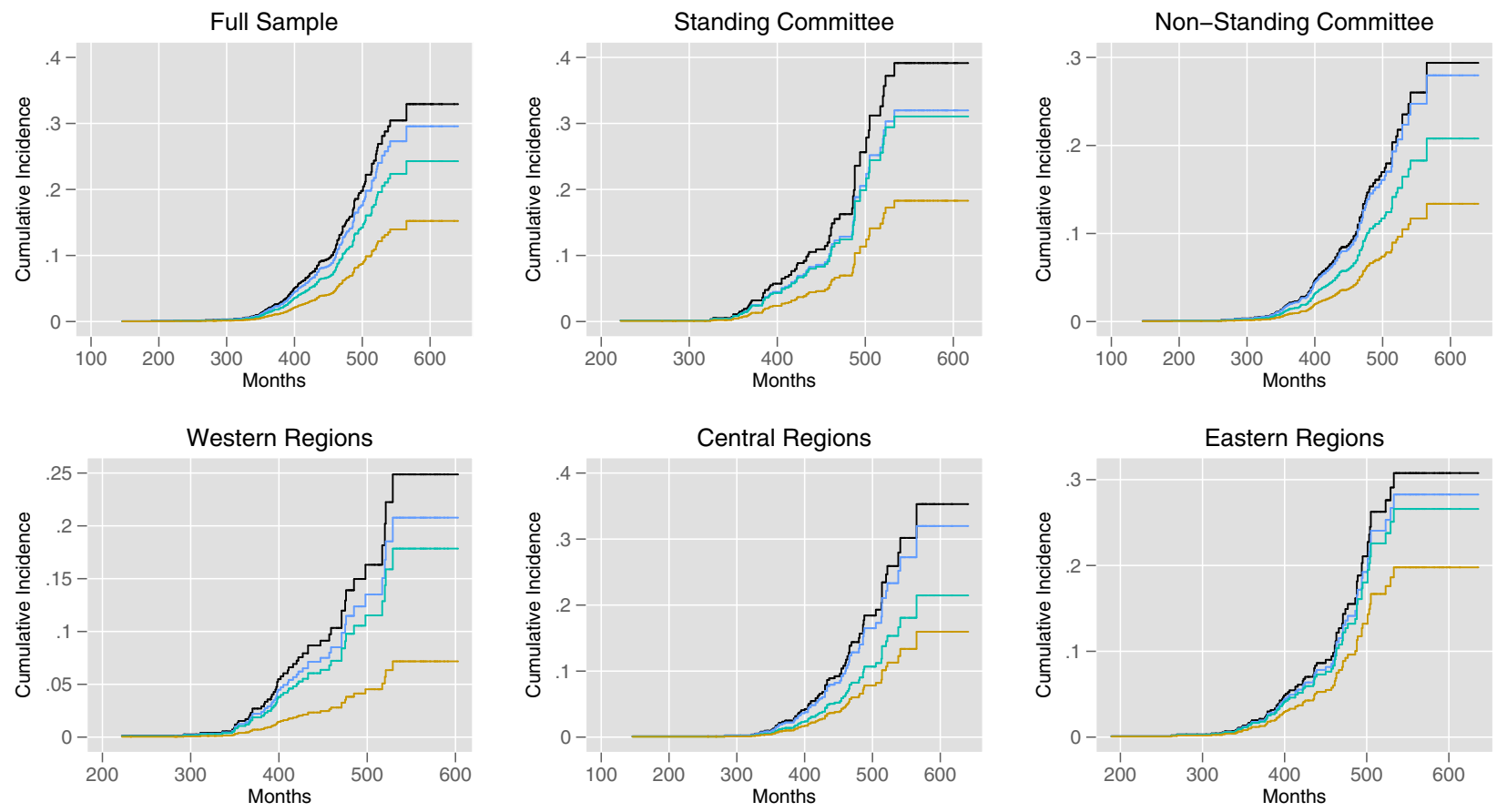

\section{- Career Starting Level = Grassroots Government Career Starting Level $=$ Provincial Government}

\section{- Career Starting Level = Municipal Government Career Starting Level $=$ Central Government}

Fig. 3 The cumulative incidence curves of risk of political falling. The cumulative incidence curves of political falling from the highest to the lowest are grassroots government beginnings, municipal government beginnings, provincial government beginnings, and central government beginnings, which indicates that deputy mayors with higher career starting levels have lower cumulative rate of political falling. Thus, deputy mayors who started in the grassroots-level governments always had the highest cumulative political falling rates.

mayors were less likely to encounter political falling. The reason may lie in the fact that these are marginalized individuals without real power, therefore, resulting in fewer opportunities for corruption. Native deputy mayors may easily gather power at the local level because of nepotism, thus breeding corruption, while deputy mayors in rapidly developing areas are also prone to corruption, as there are more temptations (Knutsen et al., 2017; Hou et al., 2018). Values related to Minority and CCYL were always lower than 1 but nonsignificant, which indicated that deputy mayors of ethnic minorities and deputy mayors with a background in the Communist Youth League may have lower probabilities of a downfall. The former may be largely because of concerns about their ethnic identity and worries about ethnic conflicts caused by the investigation and punishment of ethnic minority officials, while the reason for the latter is protection from the Tuan Pai (团派) (Pang et al., 2018b).

\section{Conclusion}

Our analysis demonstrates that political promotion and falling of Chinese officials were significantly correlated with the level of government where the officials started their official careers. The higher the career starting level was, the greater the probability of getting promotion and the lower the risk of experiencing political falling. Thus, the deputy mayors who started their careers in grassroots governments were associated with the lowest probability of promotion and the highest risk of falling.

This "birth influences future" phenomenon taking place in the Chinese official system can be seen as some kind of social stratification. The officials who started their careers in the grassroots-level governments can hardly integrate into the upper circle or build guanxi with superior leaders who hold power and are finally associated with the lowest probability of promotion and highest probability of falling. According to China's Ministry of Civil Affairs, there were 2851 counties and 39862 towns in China at the end of 2016 (The Ministry of Civil Affairs of China, 2017). The total number of civil servants in China at the end of 2016 was 7.19 million (Ministry of human resources and social security of the People's Republic of China, 2018), more than $60 \%$ of whom worked in grassroots-level governments (Website of the National People's Congress, 2015). It is the sheer number of cadres serving at the grassrootslevel governments that lays the steady foundation of the CPC's rule. Since the nationwide outbreak of coronavirus disease (COVID-19) in China, grassroots cadres have played a critical role in the battle against the COVID-19 epidemic by getting strict quarantine measures into effect. Each grassroots cadre is responsible for hundreds of residents with duties involving gatekeepers, food and medicine delivery and staying in constant contact with locals (Ian et al., 2020; Xinhua, 2020).

The grassroots cadres make the most strenuous efforts while facing the worst work environments and receiving the least reward. Moreover, according to our analysis, unfair political treatments do not match the importance of grassroots work and lead to great discontent among grassroots cadres (People's network, 2019). The tragedy of cadres starts in grassroots-level governments, which could possibly threaten the sustainability of Communist party rule in the future.

In fact, in the early years after the founding of the People's Republic of China, there were many high-ranking officials who were from the grassroots classes, such as farmers and workers. It was a time when grassroots cadres had been greatly valued, and some of 
Table 5 The logistic regression results estimating the effect of different career starting levels on political falling.

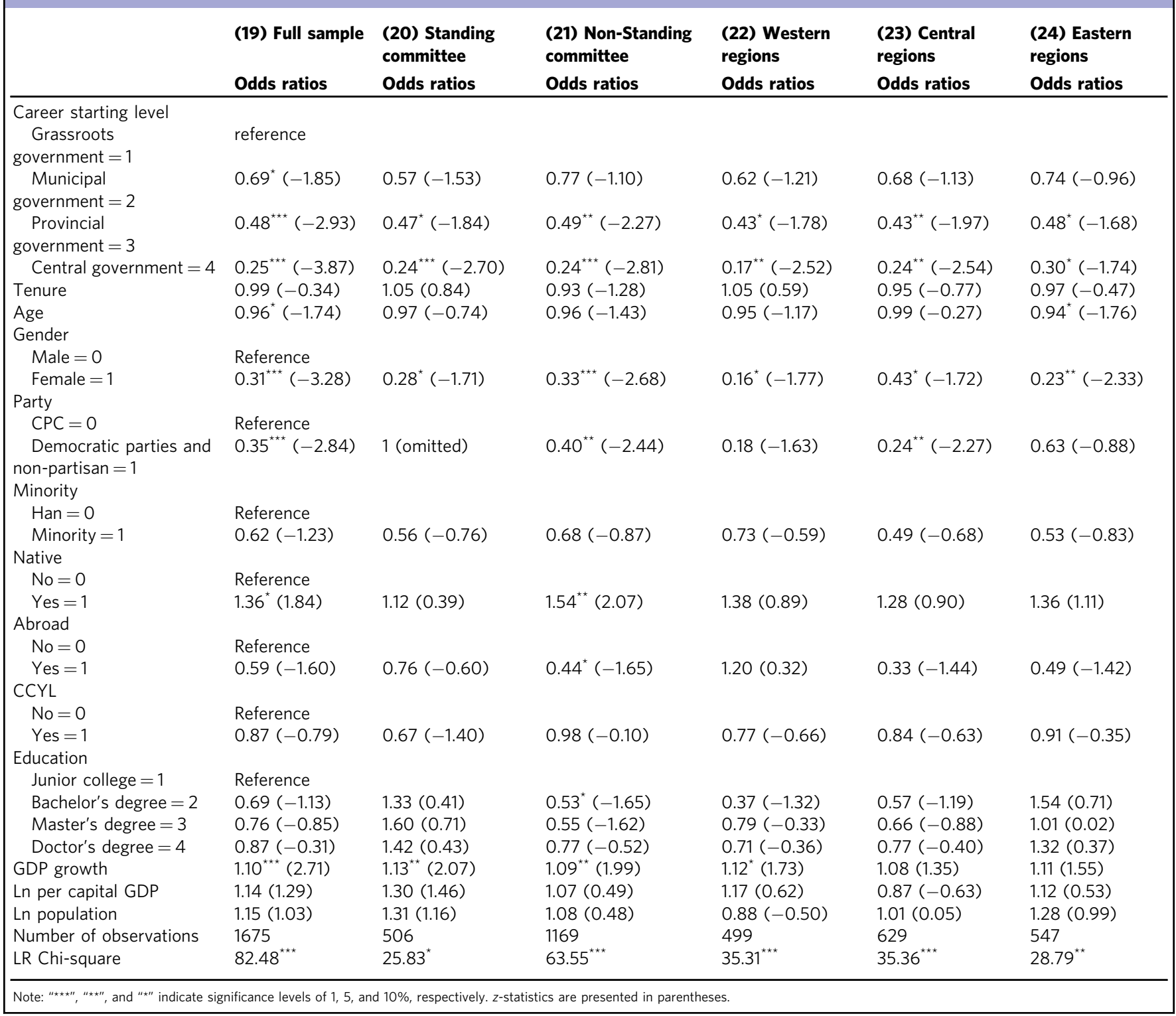

them were rapidly promoted to central leadership roles. For example, Chen Yonggui (陈永贵) was an illiterate peasant who became a member of the Politburo of the Communist Party of China and Vice Premier of the People's Republic of China. Another famous example is Wang Hongwen (王洪文), who was promoted from a position as a security guard to become one of the foremost members of the national leadership of the Communist Party of China. As the regime became increasingly stable, social classes started to become polarized and solidified. After the tax-sharing reform in 1994, the centralization of power significantly strengthened (Chen et al., 2018), which resulted in the low status of local officials and discrimination against officials with grassroots administration origins. The inequality faced by officials starting from grassroots-level governments was reflected in the gradual centralization of power and the solidification of social classes. Any lack of attention to this issue may lead to a repeat of historical tragedies.

To the best of our knowledge, this is the first study that addresses the unfair political treatment of Chinese officials with grassroots origins, the first empirical research that examines the role of career starting levels in deputy leaders' political careers and the first article that introduces the competing risk analysis method into the research examining Chinese officials' political careers. We should say there are still many questions that need to be further discussed. This study provides a wealth of information for scholars to consider. The following questions should be considered: Does the career starting level influence the future careers of the chief leaders of the party and government? Does a similar phenomenon occur in other authoritarian countries? How can this problem be resolved?

\section{Data availability}

The datasets generated and analyzed are available from the corresponding author upon reasonable request.

Received: 29 March 2020; Accepted: 12 August 2020; Published online: 25 August 2020 


\section{Notes}

1 Four standards for cadres: In the twenty-first century, national cadres should work under CPC guidance, should maintain the cadres' young age, should hold appropriate degrees and should always be professional.

2 Owing to the reliability and availability of the early data, GDP data before the year 2000 were not included in the calculation of the real GDP Growth and Ln Per Capital GDP.

3 To rule out the influence of the different sizes of public bodies and different amounts of management tiers, we excluded sub-provincial cities (fushengjishi 副省级市), prefectures (diqu 地区), autonomous prefectures (zizhizhou 自治州) and leagues (meng 盟) and only took 268 prefecture-level cities (dijishi 地级市) into account.

\section{References}

Bian Y (1994) Guanxi and the allocation of urban jobs in China. China Q 140:971. https://doi.org/10.1017/S0305741000052863

Bo Z (1996) Economic performance and political mobility: Chinese provincial leaders. J Contemp China 5:135-154. https://doi.org/10.1080/10670569608724246

Bo Z (2002) Governing China in the early 21st century: Provincial perspective. J Chin Polit Sci 7:125-170. https://doi.org/10.1007/BF02876931

Chen T, Wang Y, Luo X et al. (2018) Inter-provincial inequality of public health services in China: the perspective of local officials' behavior. Int J Equity Health 17:1-15. https://doi.org/10.1186/s12939-018-0827-8

Chen Y, Li H, Zhou L-A (2005) Relative performance evaluation and the turnover of provincial leaders in China. Econ Lett 88:421-425. https://doi.org/10.1016/ j.econlet.2005.05.003

Choi EK (2012) Patronage and performance: factors in the political mobility of provincial leaders in post-deng China. China Q 212:965-981. https://doi.org/ 10.1017/S030574101200118X

Dittmer L (1995) Chinese informal politics. China J 34:1-34. https://doi.org/ $10.2307 / 2950131$

Dong B, Torgler B (2013) Causes of corruption: evidence from China. China Econ Rev 26:152-169. https://doi.org/10.1016/j.chieco.2012.09.005

Falk M (2013) A survival analysis of ski lift companies. Tour Manag 36:377-390. https://doi.org/10.1016/j.tourman.2012.10.005

Fang K, Ma C (2010) Chinese government promotion principle: the sample of Beijing officials(官员如何升迁 “北京样本”折射地方官成长之路). http:// www.infzm.com/content/45151. Accessed 5 Feb 2019

Fu G, Wei J, Shi Y et al. (2018) Examining discrimination against women, non-han minorities, intellectuals, and non-communist members among the current China's provincial political elites. J Women Polit Policy 39:177-195. https:// doi.org/10.1080/1554477X.2018.1449526

Hou L, Liu M, Yang DL, Xue J (2018) Of time, leadership, and governance: elite incentives and stability maintenance in China. Governance 31:239-257. https://doi.org/10.1111/gove.12286

Ian KL, Zhou M, Wang EJY (2020) The China experience-understanding the evolution of the covid-19 crisis (updated on 6 Apr 2020). https://www. mayerbrown.com/en/perspectives-events/publications/2020/04/the-chinaexperience-understanding-the-evolution-of-the-covid-19-crisis-updated-on6-april-2020. Accessed 9 Apr 2020

Jia R, Kudamatsu M, Seim D (2015) Political selection in China: the complementary roles of connection and performance. J Eur Econ Assoc 13:631-668. https://doi.org/10.1111/jeea.12124

Knutsen CH, Kotsadam A, Olsen EH, Wig T (2017) Mining and local corruption in africa. Am J Polit Sci 61:320-334. https://doi.org/10.1111/ajps.12268

Landry PF (2003) The political management of mayors in post-deng China. Cph J Asian Stud 17:31. https://doi.org/10.22439/cjas.v17i0.12

Landry PF, Lü X, Duan H (2018) Does performance matter? Evaluating political selection along the Chinese administrative ladder. Comp Polit Stud 51:1074-1105. https://doi.org/10.1177/0010414017730078

Lee HY (1991) From revolutionary cadres to party technocrats in socialist China. University of California Press, Berkeley

Lei Z (2011) Can official rank standard affect individuals' behavior in China? -a framing effect investigation. http://excen.gsu.edu/docs/Zhen\%20Lei_11.15. 2011.pdf. Accessed 25 May 2020

Li C (2012a) The battle for China's top nine leadership posts. Wash Q 35:131-145. https://doi.org/10.1080/0163660X.2012.642788

Li C (2012b) The end of the CCP's resilient authoritarianism? A tripartite assessment of shifting power in China. China Q 211:595-623. https://doi.org/ $10.1017 /$ S0305741012000902

Li H, Zhou L-A (2005) Political turnover and economic performance: the incentive role of personnel control in China. J Public Econ 89:1743-1762. https://doi. org/10.1016/j.jpubeco.2004.06.009

Lin T (2012) The promotion logic of prefecture-level mayors in China. China Int J 10:86-109

MacFarquhar R, Schoenhals M (2006) Mao's last revolution. Belknap Press of Harvard Univ. Press, Cambridge, Mass
Ministry of human resources and social security of the People's Republic of China (2018) Statistical bulletin on the development of human resources and social security in 2016 (2016年度人力资源和社会保障事业发展统计公报) http://www.mohrss.gov.cn/SYrlzyhshbzb/zwgk/szrs/tjgb/201805/W02018052 1567132619037.pdf. Accessed 5 Feb 2019

Moody PR (2009) Political culture and the study of chinese politics. J Chin Polit Sci 14:253-274. https://doi.org/10.1007/s11366-009-9060-Z

O’Brien KJ, Li L (1999) Selective policy implementation in rural China. Comp Polit 31:167-186. https://doi.org/10.2307/422143

Opper S, Nee V, Brehm S (2015) Homophily in the career mobility of China's political elite. Soc Sci Res 54:332-352. https://doi.org/10.1016/j.ssresearch. 2015.08.007

Pang A, Hu Y, Woon E (2018a) A broad stroke or different strokes for different folks? Examining the subtleties in crisis management approaches in stateowned enterprises and privately owned enterprises in China. Chin J Commun 11:5-25. https://doi.org/10.1080/17544750.2017.1357641

Pang B, Keng S, Zhong L (2018b) Sprinting with small steps: China's cadre management and authoritarian resilience. China J 80:68-93. https://doi.org/ $10.1086 / 696870$

People's network (2019) Escape from the town! The worries of young cadres at the grassroots level governments (逃离乡镇! 基层年轻干部断层之忧, 该如何 化解?). http://m.people.cn/n4/2019/0127/c203-12252412.html. Accessed 5 Feb 2019

Perry EJ, Goldman M (2007) Grassroots political reform in contemporary China Harvard University Press, Cambridge, Mass

Porta N, Gomez G, Calle ML, Malats N (2007) Competing risks methods. https:// upcommons.upc.edu/bitstream/handle/2117/2201/TR_CR.pdf?sequence=1\& isAllowed $=\mathrm{y}$. Accessed 20 Mar 2020

Pye LW (1992) The spirit of Chinese politics, New ed. Harvard University Press, Cambridge, Mass

Shih V, Adolph C, Liu M (2012) Getting ahead in the communist party: explaining the advancement of central committee members in china. Am Polit Sci Rev 106:166-187. https://doi.org/10.1017/S0003055411000566

Sin S-CJ, Kim K-S (2008) Use and non-use of public libraries in the information age: a logistic regression analysis of household characteristics and library services variables. Libr Inf Sci Res 30:207-215. https://doi.org/10.1016/j. lisr.2007.11.008

Su F (2006) Gender inequality in Chinese politics: an empirical analysis of provincial elites. Polit Gend 2:143-163. https://doi.org/10.1017/ S1743923X06060077

Tervonen HE, Walton R, You $\mathrm{H}$ et al. (2017) After accounting for competing causes of death and more advanced stage, do aboriginal and torres strait islander peoples with cancer still have worse survival? A population-based cohort study in new south wales. BMC Cancer 17:398. https://doi.org/ 10.1186/s12885-017-3374-6

The Ministry of Civil Affairs of China (2017) Statistical bulletin on social services development in 2016 (2016年社会服务发展统计公报). http://www.mca gov.cn/article/sj/tjgb/201708/20170815005382.shtml. Accessed 5 Feb 2019

Tian Z, Bush HR (2020) Half the sky: interwoven resilience processes of women political leaders in China. J Appl Commun Res 48:70-90. https://doi.org/ 10.1080/00909882.2019.1704829

Wang J, Xie Y (2015) Feeling good about the iron rice bowl: economic sector and happiness in post-reform urban China. Soc Sci Res 53:203-217. https://doi. org/10.1016/j.ssresearch.2015.05.008

Wang M, Zhu JH, Zheng C, Mayson S (2014) Suzhi expectations for doubleshouldered academics in Chinese public universities: an exploratory case study. J Chin Hum Resour Manag 5:158-176. https://doi.org/10.1108/ JCHRM-07-2014-0019

Website of the National People's Congress (2015) There are 7.2 million civil servants in China, while $60 \%$ of them are working at grassroot level (人社部: 我 国有720多万公务员 $60 \%$ 分布在县以下机关). http://www.npc.gov.cn/npc/ xinwen/2015-03/10/content_1920709.htm. Accessed 5 Feb 2019

Xinhua (2020) Xinhua headlines: grid-based community workers power up China's grassroots coronavirus fight. http://www.xinhuanet.com/english/2020-03/01/ c 138832911.htm. Accessed 26 Mar 2020

Xu X (2012) Analysis of national policies for entrepreneurship education in China Glob Soc Educ 10:403-420. https://doi.org/10.1080/14767724.2012.710483

Ying Q, Fan Y, Luo D, Christensen T (2017) Resources allocation in Chinese universities: hierarchy, academic excellence, or both? Oxf Rev Educ 43:659-676. https://doi.org/10.1080/03054985.2017.1295930

Zeng J (2013) What matters most in selecting top Chinese leaders? A qualitative comparative analysis. J Chin Polit Sci 18:223-239. https://doi.org/10.1007/ s11366-013-9247-1

Zheng Y, Chen G (2009) Xi Jinping's rise and political implications. China Int J 07:1-30. https://doi.org/10.1142/S0219747209000235

Zheng Y, Fook LL (2003) Elite politics and the fourth generation of Chinese leadership. J Chin Polit Sci 8:65-86. https://doi.org/10.1007/BF02876950 
Zuo C (Vera) (2015) Promoting city leaders: the structure of political incentives in China China Q 224:955-984. https://doi.org/10.1017/S0305741015001289

\section{Competing interests}

The authors declare no competing interests.

\section{Additional information}

Correspondence and requests for materials should be addressed to L.H.

Reprints and permission information is available at http://www.nature.com/reprints

Publisher's note Springer Nature remains neutral with regard to jurisdictional claims in published maps and institutional affiliations. (c) (i) Open Access This article is licensed under a Creative Commons Attribution 4.0 International License, which permits use, sharing, adaptation, distribution and reproduction in any medium or format, as long as you give appropriate credit to the original author(s) and the source, provide a link to the Creative Commons license, and indicate if changes were made. The images or other third party material in this article are included in the article's Creative Commons license, unless indicated otherwise in a credit line to the material. If material is not included in the article's Creative Commons license and your intended use is not permitted by statutory regulation or exceeds the permitted use, you will need to obtain permission directly from the copyright holder. To view a copy of this license, visit http://creativecommons.org/ licenses/by/4.0/.

(C) The Author(s) 2020 